Rev. Int. Contam. Ambie. 36 (3) 677-687, 2020

https://doi.org/10.20937/RICA.53573

\title{
ANALYSIS OF POLYCYCLIC AROMATIC HYDROCARBONS (PAH) IN SOIL OF MANGROVE FOREST OF THE VENEZUELAN CARIBBEAN COAST
}

Análisis de hidrocarburos aromáticos policíclicos (HAP) en suelos de bosques de manglares de las costas del Caribe venezolano

\author{
Liliana LÓPEZ ${ }^{1 *}$, María Beatriz BARRETO², Maria do Carmo RUARO PERALBA ${ }^{3}$, \\ Eduardo BARRETO-PITTOL ${ }^{1,2}$, Salvador LO MÓNACO ${ }^{1}$ and Rut DÍAZ ${ }^{1,4}$
}

${ }^{1}$ Laboratorio de Geoquímica Orgánica, Instituto de Ciencias de la Tierra (ICT), Facultad de Ciencias, Universidad Central de Venezuela, Caracas, Venezuela. Caracas 1053

${ }^{2}$ Laboratorio de Ecología de la Vegetación. Instituto de Zoología y Ecología Tropical (IZET) Facultad de Ciencias Universidad Central de Venezuela, Caracas, Venezuela. Caracas 1053

${ }^{3}$ Instituto de Química, Universidade Federal do Rio Grande do Sul, Brazil. 474 CEP 96201-900

${ }^{4}$ Departamento de Geoquímica, Instituto de Química, Universidade Federal Fluminense, Niterói, Brazil (present address) 16 Niterói, Río de Janeiro 1151

*Author for correspondence: 1iliana.lopez@ciens.ucv.ve

(Received: March 2019; accepted: October 2019)

Key words: Morrocoy National Park, Cuare Inlet, mangroves, soluble organic matter, GC-MS, PAHs diagnostic ratios

\begin{abstract}
In order to identify the levels of contamination of mangrove soils by polycyclic aromatic hydrocarbons $(\mathrm{PAH})$, their concentration was determined by gas chromatography coupled to mass spectrometry in the fraction of aromatic hydrocarbons obtained from soluble organic matter (SOM). Soils are located in Cuare Inlet and Morrocoy National Park from Venezuela, and samples were collected in Punta La Matica (PLM) and Tucacas Bay (ETU) respectively. Naphthalene, acenaphthene, acenaphthalene, benzo(ghi)perylene, dibenzo(ah)anthracene and indene have concentrations lower than the detection threshold for the technique employed $(\leq 20 \mathrm{ng} / \mathrm{g})$. Fluorene, phenanthrene, anthracene, fluoranthene, pyrene, benzo(a)anthracene, chrysene, benzo(k)fluoranthene, benzo(b)fluoranthene and benzo(a)pyrene present concentrations ranging from 24 to $967 \mathrm{ng} / \mathrm{g}$, and in some cases were not detected $(\leq 20 \mathrm{ng} / \mathrm{g})$. The PAHs concentration are classified in a pollution level from moderate to high in ETU and low in PLM. These results indicate a major anthropogenic pollution level of soils from ETU in relation to PLM soils. Based on the fact that the PAHs detected are not substituted and dominate the 3- and 4-rings, three diagnostic ratios to identify the contamination source were calculated: [anthracene/(anthracene+phenanthrene), fluoranthene/(fluoranthene+pyrene); and benzo(a)anthracene/(benzo(a)anthracene+chrysene)]; these ratios suggest a source from combustion of organic matter. Additionally, the normalization of total PAHs related to total organic carbon (TOC) or SOM represents a linear relationship between total PAHs with PAH/TOC and PAH/SOM, and suggests that the PAHs detected are from the same source, that is, the combustion of organic matter from anthropogenic activity or natural fires.
\end{abstract}

Palabras clave: Parque Nacional Morrocoy, Golfete de Cuare, manglares, material orgánica soluble, CG-EM, HAP tasas diagnósticas 


\section{RESUMEN}

Para identificar los niveles de contaminación de suelos de manglares por hidrocarburos aromáticos policíclicos (HAP), se determinó su concentración por cromatografía de gases acoplada a espectrometría de masas en la fracción de hidrocarburos aromáticos obtenida de la materia orgánica soluble (MOS). Los suelos están ubicados en el golfete de Cuare y el Parque Nacional Morrocoy, Venezuela y fueron recolectados en la Bahía de Tucacas (ETU) y Punta La Matica (PLM). Naftaleno, acenaftaleno, acetanaftaleno, benzo(ghi)perileno, dibenzo(ah)antraceno e indeno, están en concentraciones por debajo del límite de detección de la técnica utilizada ( $\leq 20 \mathrm{ng} / \mathrm{g}$ ). Fluoreno, fenantreno, antraceno, fluoranteno, pireno, benzo(a)antraceno, criseno, benzo(k)fluoranteno, benzo(b) fluoranteno y benzo(a)pireno presentan concentraciones entre 24 y $967 \mathrm{ng} / \mathrm{g}$, y en algunos casos no fueron detectados $(\leq 20 \mathrm{ng} / \mathrm{g})$. La concentración de HAP en los sitios de muestreo los clasifica con niveles de contaminación de moderados a altos en ETU y bajos en PLM. Estos resultados indican un mayor nivel de contaminación en los suelos de ETU en comparación con los de PLM. Con base en que los HAP detectados son no sustituidos y dominan los de 3 y 4 anillos, se calcularon tres relaciones diagnósticas para la identificación de la fuente de contaminación: [antraceno/(antraceno+fenantreno), fluorantenoe/(fluoranteno+pireno) y benzo(a)antraceno/(benzo(a)antraceno+criseno)], que sugieren una fuente por combustión de materia orgánica. Adicionalmente, la normalización de los HAP respecto al carbono orgánico total (COT) y la materia orgánica soluble (SOM) sugiere una sola fuente a partir de la combustión de materia orgánica de actividad antrópica o combustión natural.

\section{INTRODUCTION}

Mangrove soils are characterized by their high organic matter content (Bouillon et al. 2003, Kristensen et al. 2008) and represent very important organic carbon sinks (Alongi 2007, 2012, McLeod et al. 2011). The need to understand the evolution of organic carbon and its reservoir in mangrove soils makes it necessary to identify the natural organic matter (Mater et al. 2004, Dittmar et al. 2006, Alongi 2007, Kristensen et al. 2009) and the one coming from contamination (Farias et al. 2008, García et al. 2008, Ranjan et al. 2012, Ranjan et al. 2015). Due to in many cases, these environments are close to urban areas, industrial facilities and additionally are areas of tourism, may be subject to possible sources of pollution by PAHs.

Polycyclic aromatic hydrocarbons (PAHs) are mainly a source of contamination of organic matter in the atmosphere (Marchand et al. 2004, Ravindra et al. 2008a, 2008b), as well as in water, soils and sediments (Walker et al. 2005, Silva et al. 2007, Itoh et al. 2010, Kafilzadeh et al. 2011, Bhupander et al. 2012, Bayen 2012, Dong et al. 2012, Tsibart and Gennadiev 2013, Kaiser et al. 2016, Wang et al. 2017). The presence of PAHs, which are absorbed by fine particles and transported through the atmosphere, is indicative of anthropogenic combustion sources (Giger and Schaffner 1978, La Flamme and
Hites 1978, Garrigues and Ewald 1983, Killops and Al-Joboori 1990, Brown and Maher 1992, Leeming and Maher 1992). These compounds can have other anthropogenic sources such as oil spills, waste oils, or outboard motors (Simpson et al. 1996). Compounds such as fluorene, phenanthrene, and anthracene have been found in estuarine sediments in areas with a high degree of hydrocarbon contamination (Killops and Readman 1985). They have also been used as oil spill-related pollution markers in mangrove ecosystems (Silva et al. 2007, Farias et al. 2008, Evans et al. 2016). Based on the PAHs detected, Leeming and Maher (1992) have described two possible anthropogenic sources: non-substituted PAHs associated with vehicular traffic, and alkylsubstituted PAHs associated with lubricants and oils used in the automotive industry. Ravindra et al. (2008a) present a review of the main PAHs sources in the atmosphere, with five major emission sources of PAHs, i.e. domestic, mobile, industrial, agricultural, and natural. The geochemical criteria to differentiate HAPs origin is based on the classification on: a) pyrolytic, represented by the incomplete combustion of recent or fossilized organic matter; $b$ ) petroleum source, from the formation of petroleum during catagenesis of organic matter, process at low temperature $\left(50-150{ }^{\circ} \mathrm{C}\right)$, and c) diagenetic, from direct biosynthesis of microorganisms or vegetation (Bouchez et al. 1996a). 
For identifying pollution emission sources of PAHs some diagnostic ratios are used (Ravindra et al. 2008a, Tobiszewski and Namiesnik 2012). These diagnostic ratios are based on parent PAHs, others on the proportion of alkyl-substituted for non-substituted molecules. These ratios distinguish PAHs pollution originating from petroleum products, petroleum combustion and biomass or coal burning. The compounds involved in each ratio have the same molar mass, so it is assumed they have similar physical and chemical properties (Tobiszewski and Namieśnik 2012). In this study PAHs and their diagnostic ratios were used to identify the degree of contamination and the possible emission sources in soils of mangrove from the Cuare Inlet and Morrocoy National Park, located in Venezuela's central-western coast (Fig. 1).

\section{SAMPLES AND METHODS}

\section{Study area}

The Wildlife Refuge of Cuare and the National Park of Morrocoy are located on the central-western coast of Venezuelan Caribbean Coast (Fig. 1); they represent one of the most important marine coastal sectors because of their tourism attractions. Both protected areas comprise muddy coastal plains with mangroves and extensive salt pans, swamps and

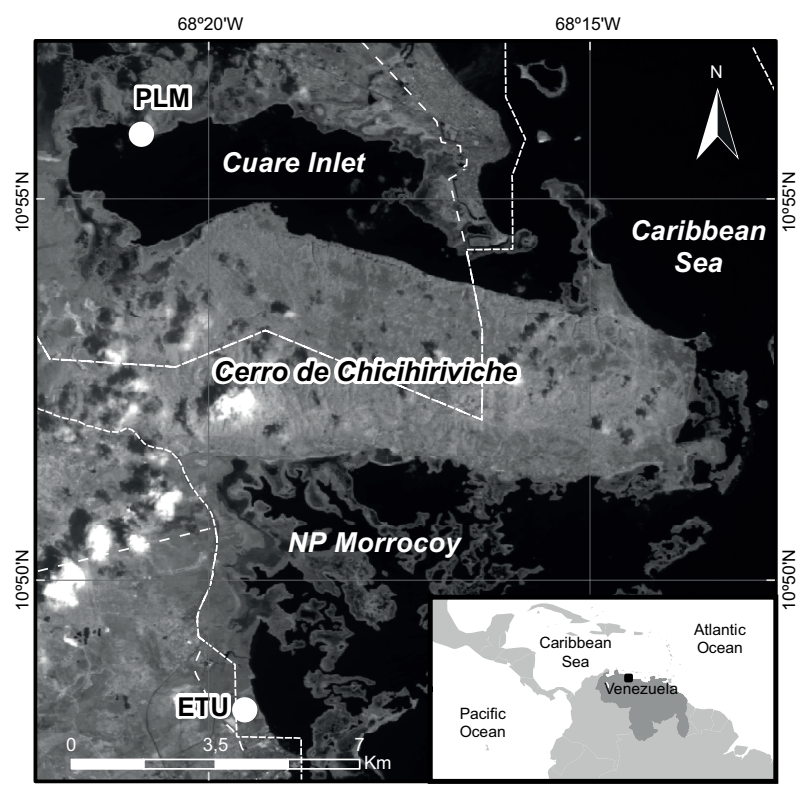

Fig. 1. Morrocoy National Park and Cuare Inlet, Venezuela. Venezuelan Remote Sensing Satellite (VRSS-1) image, April 2012 inlets, several carbonate islands of flat topography and partially covered by mangroves, and some other littoral communities (Barreto 2008).

The mangroves of Punta La Matica (PLM), are located in the northwest end of the Cuare Inlet. The low intertidal zone of mangroves is dominated by Rhizophora mangle. The sampling sites at National Park (NP) and Morrocoy (ETU), located in muddy coastal plains, are influenced by a supply of freshwater from the continent. These watercourses have short trajectories and originate in micro-basins located near the coast. They are permanent, but their flow is highly variable and increases substantially during the wet season. These watercourses have been modified by human activities (Barreto 2008).

\section{Sample collection}

Superficial $(0-20 \mathrm{~cm})$ soil samples were collected at two locations throughout the Cuare Inlet and the NP Morrocoy: Punta La Matica (PLM) and Tucacas Bay (ETU) (Fig. 1). Samples sites location was chosen taking into account the higher level of anthropogenic influence present in ETU (García et al. 2008) compared to PLM. In PLM two soil samples were collected, located in the low intertidal zone, and characterized by the presence of Rhizpophora-Laguncularia and mixed Rhizophora-LagunculariaAvicennia forest. In Tucacas Bay (ETU) seven soil samples were collected along the edge of the bay, in a transect of $70 \mathrm{~m}$ in length, characterized by a mixed forest dominated by Rhizophora and a monospecific Avicennia forest present after the first $50 \mathrm{~m}$ of the transect (Fig. 1). The locations were georeferenced using a model GPSmap 76Cx Garmin global positioning system (GPS) receiver with $\pm 3 \mathrm{~m}$ precision. The soil samples were collected using a steel soil corer $10.2 \mathrm{~cm}$ in diameter. In each sampling area, the mangrove species and stand conditions (live, deteriorated, or dead mangrove) were identified. The samples were stored in plastic bags until they were transported to the lab.

\section{Sample handling}

Samples were placed in plastic containers and left to dry at room temperature. The physical description of the samples was done with the dry material and took into account Munsell's color chart (Munsell 1973), granulometry, the presence or absence of roots, and other significant characteristics. After, the samples were ground crushing and sieved $(2 \mathrm{~mm}$ mesh size) into medium sand and clay size fractions for later chemical analyses. Prior to the chemical analyses, the samples were washed with distilled 
water to eliminate any salts (mainly sodium chloride) precipitated as a result of the drying process. Two techniques were used: filtration by means of long stem funnels and filter paper (Whatman No. 3) for samples with a high root content, and centrifugation and decantation of remaining water for samples with a high content of fine sand, silt, and clay size fractions. To corroborate that excess salts were removed, the chloride test was performed using silver nitrate. After washing, the samples were placed in an oven at $40{ }^{\circ} \mathrm{C}$ until they were completely dry (Cerqueira et al. 2019).

\section{Determination of total carbon (TC), total organic carbon (TOC), and inorganic carbon (IC)}

TC concentration was analyzed in samples using a Leco (C-144) carbon analyzer, and carbonatic or inorganic carbon (IC) was determined using the Bernard calcimeter method (Hesse 1971). Calibration curves were constructed to determine sample concentration of organic and inorganic carbon. Certified Leco patterns were used to determine TC, and patterns with different $\mathrm{CaCO}_{3}$ concentrations for IC. TOC concentration was obtained by the difference between TC and IC

\section{Extraction of soluble organic matter (SOM)}

The extraction of SOM corresponding to the lipid fraction was performed. Approximately $20 \mathrm{~g}$ of soil were weighed in cellulose thimbles and the SOM was extracted with dichloromethane in a Soxhlet extractor. The extracts were then vacuum evaporated and quantified.

\section{Analysis of polycyclic aromatic hydrocarbons (PAHs)}

To determine the PAHs, a fraction of the extracted SOM was separated by absorption column chromatography using packed columns $(20 \mathrm{~cm}$ long and $1.5 \mathrm{~cm}$ in diameter) with alumina as the stationary phase $(20 \mathrm{~g})$. The saturated hydrocarbons were eluted with $n$-hexane $(30 \mathrm{~mL})$, and the aromatic hydrocarbons with toluene $(20 \mathrm{~mL})$.

The following PAHs were analyzed: naphthalene, acenaphthalene, acenaphthene, fluorene, phenanthrene, anthracene, fluoranthene, pyrene, benzo(a)anthracene, chrysene, benzo(k)fluoranthene, benzo(b) fluoranthene, benzo(a)pyrene, benzo(ghi)perylene, dibenzo(ah)anthracene and indene. The internal perdeuterated PAHs standard mix [naphthalene $\mathrm{d}_{8}$ (99\%), acenaphthene $d_{10}(98 \%)$, phenanthrene $d_{10}$ (98\%) chrysene $d_{12}(98 \%)$ and perylene $\left.d_{12}(98 \%)\right]$ was purchased from Cambridge Isotope Laboratories and the 16 PAHs USEPA priority standard [naphthalene, acenaphthylene, acenaphthene, fluorene, phenanthrene, anthracene, fluoranthene, pyrene, benzo(a)anthracene, chrysene, benzo(b)fluoranthene, benzo(k)fluoranthene, benzo(a)pyrene, indene(1,2,3$\mathrm{c}, \mathrm{d})$ pyrene, benzo(g,h,i)perylene and dibenzo(a,h) anthracene] was purchased from Supelco.

The quantitative analysis of regular PAHs and alkylated homologues was carried out using the internal standard method using as standards the perdeuterated naphthalene $\mathrm{d} 8$, acenaphthene $\mathrm{d} 10$, phenanthrene $\mathrm{d} 10$, chrisene $\mathrm{d} 12$ and perylene $\mathrm{d} 12$. The calibration curves were established using a standard mixture of 16 priory PAHs and the perdeuterated standards above mentioned.

The identification and quantification of the 16 polycyclic aromatic compounds (alkylated and non alkylated) was carried out using a gas chromatograph Agilent, model 6890 with automatic injector and fused silica capillary column ( $30 \mathrm{~m} \times 0.25 \mathrm{~mm}$ x 0.25 $\mathrm{mm}$ ) with $5 \%$ phenyl - $95 \%$ dimethylpolysiloxane stationary phase. He, with a flow of $1 \mathrm{~mL} / \mathrm{min}$, was used as carrier gas. A selective mass detector Agilent 5976 operating in the electronic impact ionization mode $(70 \mathrm{eV})$ and single ion monitoring (SIM) was employed for data acquisition (Peters et al. 2005). An amount of $1 \mathrm{~mL}$ of the extract was injected in splitless mode using the following chromatographic conditions: injector temperature $=290{ }^{\circ} \mathrm{C}$; initial column temperature $=40^{\circ} \mathrm{C}$ isothermal for $1 \mathrm{~min}$, heating rate $6{ }^{\circ} \mathrm{C} / \mathrm{min}$ until $290{ }^{\circ} \mathrm{C}$ and isothermal for $20 \mathrm{~min}$. The monitored ions for polyaromatic analysis were: $\mathrm{d} 8$ naphthalene $(\mathrm{m} / \mathrm{z}=136)$, benz(a) anthracene $(m / z=228)$, naphthalene $(m / z=128)$, crysene $(m / z=228)$, d10 acenaphthene $(\mathrm{m} / z=164)$, d12 perylene $(\mathrm{m} / \mathrm{z}=264)$, acenaphthylene $(\mathrm{m} / \mathrm{z}=$ $152)$, benz $(\mathrm{k})$ fluoranthene $(\mathrm{m} / \mathrm{z}=252)$, acenaphthene $(\mathrm{m} / \mathrm{z}=154)$, benzo(a)pyrene $(\mathrm{m} / \mathrm{z}=252)$, fluorine $(\mathrm{m} / z=166)$, benzo(ghi)perylene $(\mathrm{m} / \mathrm{z}=276), \mathrm{d} 10$ fenantrene $(\mathrm{m} / \mathrm{z}=188)$, indeno(123-cd)pyrene $(\mathrm{m} / \mathrm{z}$ = 276), fenantreno $(m / z=178)$, dibenzo(ah)anthracene $(\mathrm{m} / \mathrm{z}=278)$, anthracene $(\mathrm{m} / \mathrm{z}=178)$, benzo(b) fluoranthene $(\mathrm{m} / \mathrm{z}=252)$, fluoranthene $(\mathrm{m} / \mathrm{z}=202)$ and pyrene $(\mathrm{m} / \mathrm{z}=202)$.

\section{RESULTS AND DISCUSSION}

In samples IC is below the detection limit of the method (Bernard calcimeter $\leq 4$ ). Additionally the soils are characterized by the absence of carbonates and their mineralogy is siliciclastic with the presence of quartz, kaolinite, illite and pyrite (Barreto et 
al. 2016). Therefore, the total carbon determined by Leco represents the total organic carbon (TOC) in the soils. TOC have concentrations between $9.7 \%$ to $14.9 \%$ in ETU and 11.3 to $19.5 \%$ in PLM; however, the amount of lipid fraction, represented by soluble organic matter $(\mathrm{SOM})$, is very low $(<1 \%)$ and the soluble organic matter/total organic carbon ratio is also very low $(\mathrm{SOM} / \mathrm{TOC}<0.01)$ (Table I) compared to other mangrove soils (Barreto et al. 2016).

TABLE I. TOTAL ORGANIC CARBON (TOC wt \%), SOLUBLE ORGANIC MATTER (SOM wt \%) AND SOM/TOC RATIO

\begin{tabular}{lcccc}
\hline Site & Samples & $\begin{array}{c}\text { TOC } \\
(\text { wt } \%)\end{array}$ & $\begin{array}{c}\text { SOM } \\
(\text { wt } \%)\end{array}$ & SOM/TOC \\
\hline & ETU-1 & 12.5 & 0.52 & 0.04 \\
& ETU-2 & 12.3 & 0.54 & 0.04 \\
Tucacas & ETU-3 & 11.4 & 0.52 & 0.05 \\
Bay & ETU-4 & 14.9 & 0.84 & 0.06 \\
& ETU-5 & 10.1 & 0.82 & 0.08 \\
& ETU-6 & 13.7 & 0.99 & 0.07 \\
\hline Punta & ETU-7 & 9.7 & 0.53 & 0.05 \\
La Matica & PLM-1 & 19.5 & 0.68 & 0.04 \\
\hline
\end{tabular}

ETU $=$ Tucacas Bay, PLM = Punta La Matica, inorganic carbon in all samples $\leq 4 \%$. TOC $=$ total organic carbon, $\mathrm{SOM}=$ soluble organic matter, $\mathrm{SOM} / \mathrm{TOC}=$ soluble organic matter/ total organic carbon.

Individual PAH concentrations are shown in table II, their concentration was $\leq 967 \mathrm{ng} / \mathrm{g}$; in some cases they were not detected as they were lower than the detection threshold for the technique employed $(\leq 20 \mathrm{ng} / \mathrm{g})$. This was true for naphthalene, acenaphthene, acenaphthalene, benzo(ghi)perylene, dibenzo(a,h)anthracene, and indene. None of the PAHs analyzed were detected in the ETU-1 sample; only fluorene was detected in the ETU-2 sample; and ETU-5 was the only sample characterized by the presence of benzo(k)fluoranthene, benzo(b)fluoranthene, and benzo(a)pyrene. On the other hand, phenanthrene was detected in most of the samples and is the PAH found in highest concentration, followed by fluoranthene, pyrene, and chrysene. The rest of the PAHs analyzed (fluorene, anthracene, and benzo(a) anthracene) had concentrations of $<100 \mathrm{ng} / \mathrm{g}$. In the PLM soils, the PAHs detected (phenanthrene, fluoranthene, and pyrene) were present in smaller concentrations that in the ETU soils. Table II also shows the concentration of PAHs in ETU and PLM samples, indicating that only phenanthrene, fluoranthene and pyrene have appreciable concentrations in both locations. In PLM the other analyzed PAHs are in concentrations lower than the detection limit $(\leq 20 \mathrm{ng} / \mathrm{g})$, but in ETU chrysene, benzo(a)anthracene and benzo(k)fluoranthene present concentrations greater than $20 \mathrm{ng} / \mathrm{g}$, but not exceeding $300 \mathrm{ng} / \mathrm{g}$. These results reveal that the soils PAHs content is relatively lower in two locations, but their concentration is higher than ETU to PLM.

The total aromatic concentrations calculated by adding the PAHs concentrations detected by samples site (total PAHs = SPAH detected in sample site), are in the range between 399-2239 $\mathrm{ng} / \mathrm{g}$ and 80-270 ng/g to ETU and PLM, respectively (Table II). The graphic representation between the total PAHs and TOC or SOM content in soil (Fig. 2) shows that there is no relationship between these variables. This is a consequence of the fact that both TOC and SOM represent the organic compounds of anthropogenic origin (PAHs and others do not identify in this study), the supply or organic matter of the mangroves vegetation (autochthonous organic matter) and that coming from other natural sources (autochthonous or allochthonous organic matter). Therefore, variations in the concentration of PAHs in the different sampling points can be masked by the content of organic matter of natural origin (TOC and SOM); this may avoid determining any relationship between these parameters. As consequence, the concentration of total PAHs was normalized relate to TOC (total PAHs/TOC $=$ SPAHs detected in sample site/Total Organic Carbon) and SOM (total PAHs/ SOM = SPAHs detected in sample site/Soluble Organic Matter) according to López et al. (2000) (Table II). In figure 3, the graphical relationship between total PAHs with PAHs/TOC $(r=0.9769)$ and PAHs/SOM $(r=0.8877)$ is represented, where a linear relationship with a high correlation coefficient between these variables is observed. These results suggest that the PAHs detected come from the same source. In this graphic, the sampling point where the concentration of all PAHs was below the detection limit $(\leq 20 \mathrm{ng} / \mathrm{g})$ was included (ETU-1), as a measure of the minimum value of contamination determined. On the other hand, according to values of these ratios in the sampling sites and the location in the graph of figure 3, PAHs/TOC and $\mathrm{PAHs} / \mathrm{SOM}$ are in the order: a) ETU-2 $>$ ETU-6 $>$ ETU-3 $>$ ETU-5 $>$ ETU $7>$ ETU-4 $>$ PLM-0 $>$ PLM- $1>>>>$ ETU-1 and b) ETU-2 $>$ ETU-3 $>$ ETU-6 $>$ ETU-5 $>$ ETU $7>$ ETU-4 $>$ PLM-0 $>$ PLM- $1>>>$ ETU1 respectively. Again, these graphs show a higher level of PAHs in ETU relate to PLM. 
TABLE II. INDIVIDUAL POLYCYCLIC AROMATIC HYDROCARBONS (PAHs), TOTAL PAHs CONCENTRATION (ng/g), AND CALCULATED RATIOS FROM SOIL SAMPLES OF TUCACAS BAY (ETU) AND PUNTA LA MATICA (PLM).

\begin{tabular}{|c|c|c|c|c|c|c|c|c|c|c|}
\hline \multirow[b]{2}{*}{ PAH } & \multicolumn{7}{|c|}{ ETU } & \multicolumn{3}{|c|}{ PLM } \\
\hline & 2 & 3 & 4 & 5 & 6 & 7 & $\sum$ PAHs & 1 & 2 & $\sum$ PAHs \\
\hline Fluorene & 44 & $\leq 20$ & $\leq 20$ & $\leq 20$ & $\leq 20$ & $\leq 20$ & 44 & $\leq 20$ & $\leq 20$ & $\leq 20$ \\
\hline Phenanthrene & 967 & 707 & 301 & $\leq 20$ & 718 & 197 & 2891 & 98 & 80 & 177 \\
\hline Anthracene & 37 & 26 & 24 & $\leq 20$ & 41 & $\leq 20$ & 128 & $\leq 20$ & $\leq 20$ & $\leq 20$ \\
\hline Fluoranthene & 506 & 253 & 68 & 110 & 354 & 75 & 1366 & 83 & $\leq 20$ & 83 \\
\hline Pyrene & 570 & 245 & 68 & 133 & 354 & 76 & 1446 & 89 & $\leq 20$ & 89 \\
\hline Benzo(a)anthracene & 42 & 27 & $\leq 20$ & 97 & 47 & $\leq 20$ & 213 & $\leq 20$ & $\leq 20$ & $\leq 20$ \\
\hline Chrysene & 73 & 38 & $\leq 20$ & 282 & 156 & 51 & 600 & $\leq 20$ & $\leq 20$ & $\leq 20$ \\
\hline Benzo(k)fluoranthene & $\leq 20$ & $\leq 20$ & $\leq 20$ & 169 & $\leq 20$ & $\leq 20$ & 169 & $\leq 20$ & $\leq 20$ & $\leq 20$ \\
\hline Benzo(b)fluoranthene & $\leq 20$ & $\leq 20$ & $\leq 20$ & 80 & $\leq 20$ & $\leq 20$ & 80 & $\leq 20$ & $\leq 20$ & $\leq 20$ \\
\hline Benzo(a)pyrene & $\leq 20$ & $\leq 20$ & $\leq 20$ & 100 & $\leq 20$ & $\leq 20$ & 100 & $\leq 20$ & $\leq 20$ & $\leq 20$ \\
\hline $\mathrm{An} /(\mathrm{An}+\mathrm{Phe})$ & 0.04 & 0.04 & 0.07 & $\mathrm{NC}$ & 0.05 & $\mathrm{NC}$ & --- & $\mathrm{NC}$ & $\mathrm{NC}$ & -- \\
\hline F1/(F1+Py) & 0.47 & 0.51 & 0.50 & 0.45 & 0.50 & 0.50 & --- & 0.48 & $\mathrm{NC}$ & --- \\
\hline $\mathrm{b}(\mathrm{a}) \mathrm{An} / \mathrm{b}(\mathrm{a}) \mathrm{An} / \mathrm{Ch}$ & 0.37 & 0.42 & $\mathrm{NC}$ & 0.26 & 0.23 & $\mathrm{NC}$ & --- & $\mathrm{NC}$ & $\mathrm{NC}$ & --- \\
\hline Total PAHs & 2239 & 1296 & 461 & 971 & 1670 & 399 & --- & 270 & 80 & --- \\
\hline Total PAHs/TOC & 182 & 114 & 31 & 96 & 122 & 41 & --- & 14 & 7 & --- \\
\hline Total PAHs/SOM & 4146 & 2492 & 549 & 1184 & 1687 & 753 & --- & 397 & 93 & --- \\
\hline
\end{tabular}

ETU $=$ Tucacas Bay, PLM = Punta La Matica, naphthalene, acenaphthene, acenaphthylene, benzo(ghi)perylene, dibenzo(ah)anthracene and indene $\leq 20 \mathrm{ng} / \mathrm{g}$, in ETU- $1=$ all PAHs $\leq 20 \mathrm{ng} / \mathrm{g}, \mathrm{NC}=$ not calculated, $\Sigma \mathrm{PAHs}=$ individual PAH total concentration, An/(An+Phe) $=$ anthracene/(anthracene+phenanthrene), $\mathrm{Fl} /(\mathrm{Fl}+\mathrm{Py})=$ fluoranthene/(fluoranthene+pyrene), $\mathrm{b}(\mathrm{a}) \mathrm{An} / \mathrm{b}(\mathrm{a}) \mathrm{An} / \mathrm{Ch}=\mathrm{benzo}(\mathrm{a})$ anthracene/ (benzo(a)anthracene + chrysene), total PAHs $=\Sigma$ PAHs detected in sample site, total PAHs/TOC $=\Sigma$ PAHs detected in sample site/total organic carbon, ' total $\mathrm{PAHs} / \mathrm{SOM}=\Sigma \mathrm{PAHs}$ detected in sample site/soluble organic matter.
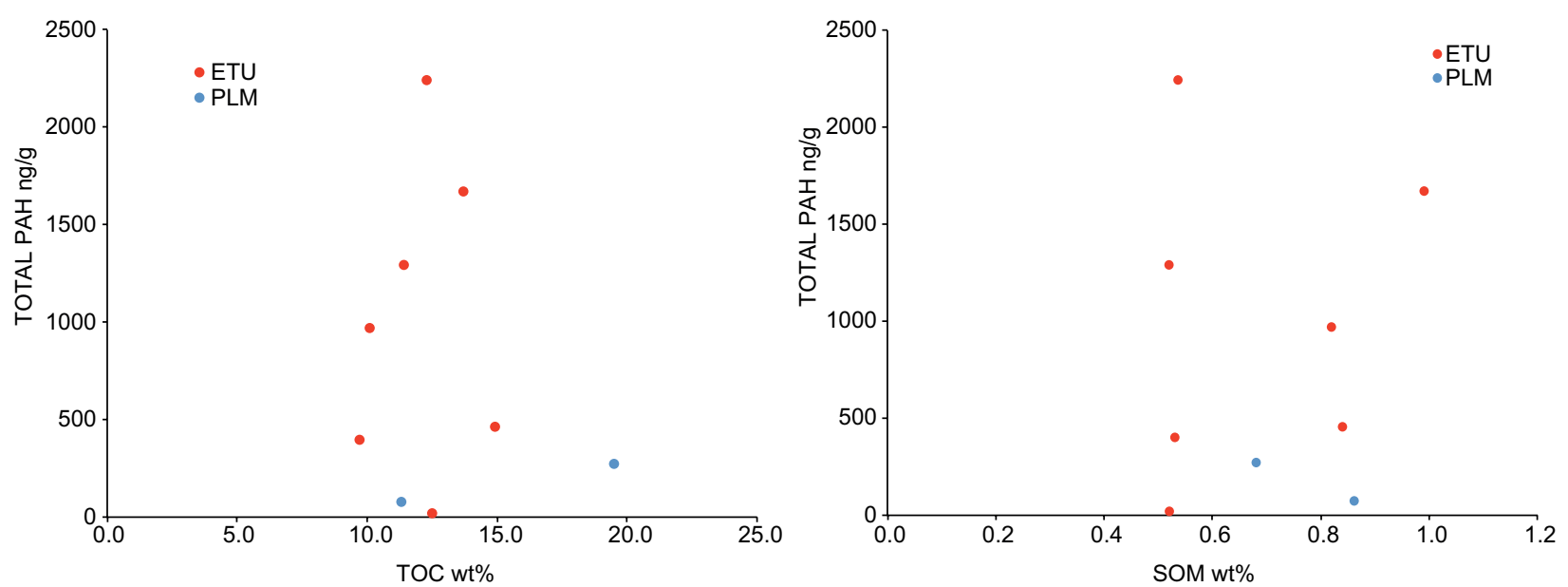

Fig. 2. Relationship between total polycyclic aromatic hydrocarbons (PAHs) with total organic carbon (TOC) and soluble organic matter (SOM) in soils from mangrove forest from Tucacas Bay (ETU) and Punta La Matica (PLM).

Moreover, samples were classified according to the number of PAHs rings observed and yielded the following results: a) indene, the six-ring PAH analyzed, was not detected; b) no five-ring PAHs were detected in the PLM samples and only one was detected in the ETU samples (ETU-5); c) ETU samples are characterized by the presence of PAHs with three to five-membered rings with total individual PAHs total concentration ( $\mathrm{PPAHs}$ ) between 44 and 2891 $\mathrm{ng} / \mathrm{g}$, the least abundant of which is fluorene and the most abundant phenanthrene; d) three and fourring PAHs were observed in the PLM samples, with concentration levels ( $\Sigma \mathrm{PAHs}$ ) of $83 \mathrm{ng} / \mathrm{g}$ for fluoranthene and $177 \mathrm{ng} / \mathrm{g}$ for phenanthrene and e) PAHs 

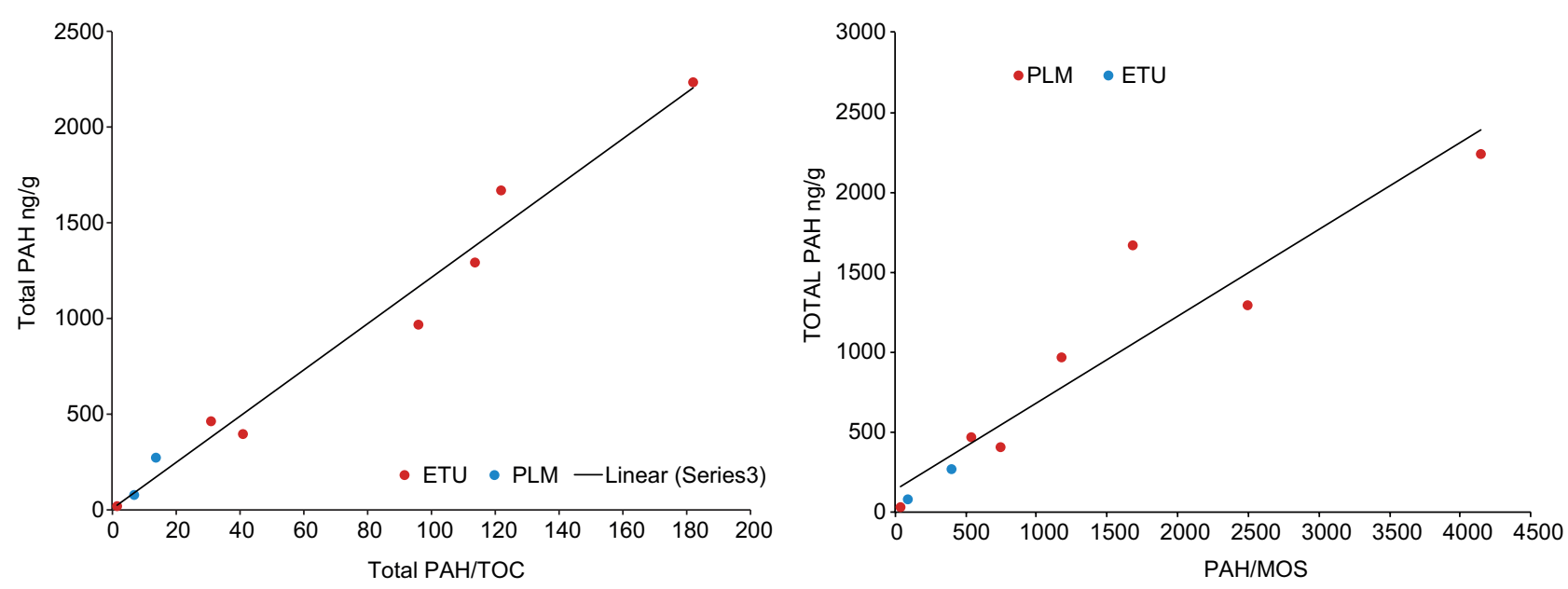

Fig. 3. Relationship between total polycyclic aromatic hydrocarbons (PAHs) with total polycyclic aromatic hydrocarbons normalized to total organic carbon (TOC) and soluble organic matter (SOM) in soils from mangrove forest from Tucacas Bay (ETU) and Punta La Matica (PLM).

concentration levels were higher in ETU samples than in PLM samples. In general, the prevalence of three and four-ring PAHs reflects the origin of combustion products, products of low-temperature pyrolytic processes, or petrogenetic sources (Dong et al. 2012). Additionally, the PAHs identified in the soils of the Cuare Inlet and the Morrocoy National Park were of the non-substituted type, which suggests petroleum combustion, as the main source, due to PAHs from pyrolytic source are characterized by high molecular weight non-alkylated aromatic compounds (Volkman et al. 1997). The products of combustion are probably transported in particulated form to the soils or sediments in this area.

On the other hand, the ratios used to identify pollution emission sources are based on the proportion

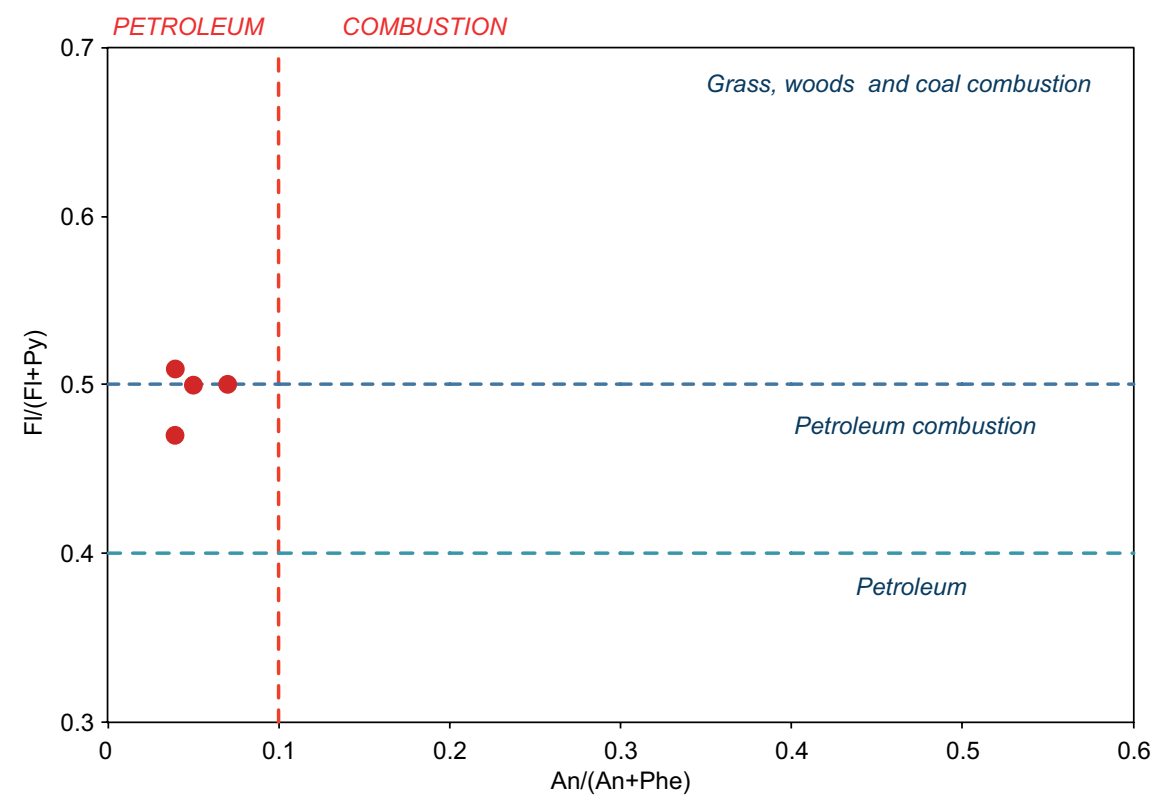

Fig. 4. Polycyclic aromatic hydrocarbons cross plots for fluoranthene/(fluoranthene+pyrene) $[\mathrm{Fl} /(\mathrm{Fl}+\mathrm{Py})]$ vs. anthracene/(anthracene+phenanthrene) $[\mathrm{An} /(\mathrm{An}+\mathrm{Phe})]$ ratios (Dong et al. 2012). 
of non-substituted PAHs. Sources are classified into: 1) petrogenetic sources from oil spills, 2) pyrolytic sources from incomplete combustion or pyrolysis of fossil fuels, and 3) sources derived from the burning of biomass or carbon (Boumar et al. 1998, Ravindra et al.2008a, 2008b, Tobiszewski and Namiesnik 2012, Tobiszewski 2014, Zhang et al. 2014, Evans et al. 2016). These ratios can have some limitations depending on the changes in the concentration of the PAHs involved, for example, the accumulation and biodegradation of phenanthrene and fluoranthene by algae present in mangrove ecosystems (Hong et al. 2008), their alteration in the atmosphere due to photodegradation, or to the reaction of PAHs to other atmospheric elements such as ozone and/or nitrogen oxides (Yunker et al. 2002, Rivandra et al. 2008a, 2008b, Tobiszewski and Namiesnik 2012). All of these could limit the usefulness of the values obtained with these ratios as indicators of source. Nevertheless, PAHs ratios are widely used in the literature to identify pollution emission sources and many of them are biodegradation-recalcitrant compounds (Khalili et al. 1995, Bouchez et al. 1996b, Hwang et al. 2003, Ravindra et al. 2008a, 2008b, Zhang et al. 2014).

From results, only three ratios could be calculated for six of the ETU samples and one PLM sample (Table II) with the following results: a) anthracene/ (anthracene+phenanthrene), with values between 0.04 and 0.07 , related to a petrogenetic source; $b$ ) fluoranthene/(fluoranthene+pyrene), with values between 0.45 and 0.51 , related to pyrolytic sources or diesel fuel; and c) benzo(a)anthracene/(benzo(a) anthracene+chrysene), with values between 0.23 and 0.37 , related to the combustion of plants or a carbon source (,Hong et al. 2008, Ravindra et al. 2008a, b, Tobiszewski and Namiesnik 2012; Tobiszewski 2014). The graph of figure 4 (Dong et al. 2012), represents the relationships anthracene/(anthracene+phenanthrene) vs. fluoranthene/ (fluoranthene+pyrene) ratios in soils samples from ETU location. Results show that ratios of An/(An $+\mathrm{Phe})$ and $\mathrm{Fl} /(\mathrm{Fl}+\mathrm{Py})$ are in the range from 0.0 to $<0.1$ and 0.45 to 0.55 , in samples to ETU location, suggesting petroleum combustion sources, and also indicate a single anthropogenic source for these PAHs, from as suggested by the normalization of total PAHs to TOC or SOM. Thus, these results indicate a prevalence of three and four-ring PAHs, which together with the diagnostic ratios obtained, suggest that the source of combustion of organic matter are anthropogenic industrial activities and/ or natural fires.
Relate to contamination level by PAHs, Baurmard et al. (1998) assigned the following pollution levels in sediments of the western Mediterranean sea (French Riviera, Corsica, Sardinia): low (0-199 ng/g), moderate (100-1000 ng/g), high (1000-5000 ng/g), and very high $(>5000 \mathrm{ng} / \mathrm{g})$. This suggests a moderate to high contamination level in the case of ETU (total PAHs 399-2239 ng/g) with the presence of three (phenanthrene) and four ring (fluoranthene and pyrene) PAHs, and a low contamination level for PLM (total PAHs $80-270 \mathrm{ng} / \mathrm{g}$ ) and the presence of only three PAHs (phenanthrene, anthracene and pyrene) detected in some samples (Table II). This confirms that the anthropogenic input is lower in PLM than in ETU.

Mangrove ecosystems in coastal zones, are under crescent anthropogenic pressures from tourism, industry and other activities (Paez-Osuna 2001, Molnar 2013), in particular in the Wildlife Refuge of Cuare and the National Park of Morrocoy (Barreto 2008). However, soils samples at ETU are most exposed to possible sources of PAHs due to the intense traffic of boats with gasoline engines than mangroves soils from PLM. Also, the National Park Morrocoy, is closer to the town of Tucacas, with very high urban and tourist activity. In this area, the high vehicular traffic produces higher densities of PAHs emissions into the atmosphere from motor vehicles that use fossil fuels. Additionally, the location of a refinery in the east of the study area (El Palito), as well as petrochemical and other industries related to the production of petroleum derivatives are an important source of PHAs in the area.

\section{CONCLUSIONS}

In mangrove soils located in Cuare Inlet and Morrocoy National Park from Venezuela the PAHs detected are non-substituted, with three (phenanthrene, anthracene) and four-ring (fluoranthene, pyrene, benzo(a)anthracene, chrysene). The other PAHs (naphthalene, acenaphthene, acenaphthalene, benzo(ghi)perylene, dibenzo(a,h)anthracene, and indene) were not detected $(\leq 20 \mathrm{ng} / \mathrm{g})$.

The three PAHs diagnostic ratios calculated a) anthracene/(anthracene+phenanthrene), (b) fluoranthene/(fluoranthene+pyrene); and (c) benzo(a) anthracene/(benzo(a)anthracene+chrysene), suggest a combustion source.

The PAH/TOC and PAH/SOM ratios present a linear relationship with total PAHs, and suggest that the PAHs detected come from the same source, that is, the combustion of organic matter, whose possible source is industrial activity or natural fires. 
The sample sites are classified according to thefollowing pollution levels: a) moderate to high in ETU (total PAHs 399-2239 ng/g) with the presence of three (phenanthrene) and four ring (fluoranthene and pyrene) PAHs, b) low for PLM (total PAHs 80-270 ng/g) with the presence of only three PAHs (phenanthrene, anthracene and pyrene). This result indicates more anthropic contribution to soils from ETU compared to soils from PLM.

\section{ACKNOWLEDGMENTS}

This work was funded by research grants from the Consejo de Desarrollo Científico y Humanístico of the Universidad Central de Venezuela (CDCH-UCV), under research grants: PG03-00-5884-2005/1 and PG-03-00-5885-2005/1 and the Fondo Nacional de Ciencia Tecnología e Innovación (FONACIT), under research grant G-2012002299.

\section{REFERENCES}

Alongi D.M. (2007). The contribution of mangrove ecosystems to global carbon cycling and greenhouse gas emissions. In: Greenhouse gas and carbon balances in mangrove coastal ecosystems. (Y. Tateda, R. Upstill-Goddard, T. Goreau, D. Alongi, A. Nose, E. Kristensen, G. Wattayakorn, Eds.), CRIEPI, Tsukoba, Tokyo, Japan, pp. 1-10.

Alongi D.M. (2012). Carbon sequestration in mangrove forests. Carbon Manag. 3 (3), 313-322. https://doi. org $/ 10.4155 / \mathrm{cmt} .12 .20$

Barreto M.B. (2008). Diagnostics about the state of mangroves in Venezuela: Case studies from the National Park Morrocoy and Wildlife Refuge Cuare, In: Mangroves and Halophytes, Restoration and Utilization. (H. Lieth, M. Garcia, B. Herzog, Eds.). Springer, Dordrecht, Holland, pp 51-64. https://doi.org/10.1007/9781-4020-6720-4 6

Barreto M.B., Lo Mónaco S., Díaz R., Barreto-Pitol E., López L. and Ruaro Peralba M.C. (2016). Soil organic carbon of mangrove forests (Rhizophora and Avicennia) of the Venezuelan Caribbean coast. Org. Geochem. 100, 51-61. https://doi.org/10.1016/j.orggeochem.2016.08.002

Baumard P., Budzinski H. and Garrigues P. (1998). Polycyclic aromatic hydrocarbons (PAHs) in sediments and mussels of the western Mediterranean Sea. Environ. Toxicol. Chem. 17 (5), 765-776. https://doi. org/10.1002/etc.5620170501
Bayen S. (2012). Occurrence, bioavailability and toxic effects of trace metals and organic contaminants in mangrove ecosystems: A review. Environ. Int. 48, 84-101. https://doi.org/10.1016/j.envint.2012.07.008

Bouillon S., Dahdouh-Guebas F., Rao A.V.V.S., Koedam N. and Dehairs F. (2003). Sources of organic carbon in mangrove sediments: variability and possible implications for ecosystem functioning. Hydrobiologia 495 (1), 33-39. https://doi.org/10.1023/A:1025411506526

Brown G. and Maher W. (1992). The occurrence, distribution and sources of polycyclic aromatic hydrocarbons in the sediments of the Georges River estuary, Australia. Org. Geochem.18 (5), 657-668. https://doi. org/10.1016/0146-6380(92)90091-B

Bhupander K., Gargi G., Richa G., Dev P., Sanjay K. and Shekhar S.S. (2012). Distribution, composition profiles and source identification of polycyclic aromatic hydrocarbons in roadside soil of Delhi India. J. Environ. Earth. Health. Sci. 2 (1), 10-23.

Bouchez M., Blanchet D., Vandecasteele J.P. and Haeseler F. (1996a). Les hydrocarbures aromatiques polycycliques dans l'environnement. Première partie. propriétés, origines, devenir. Oil. Gas. Sci. Technol - Rev. Inst. Fr. Pét. 51 (3), 407-419. https://doi.org/10.2516/ ogst:19966031

Bouchez M., Blanchet D., Vandecasteele J.P. and Haeseler F. (1996b). Les hydrocarbures aromatiques polycycliques dans l'environnement: La dégradation par voie microbienne: Oil. Gas. Sci. Technol - Rev. Inst. Fr. Pét. 51 (6), 797-828. https://doi.org/10.2516/ogst:1996052

Cerqueira A., Costa C., Rocha F., Sequeira C. and Terroso D. (2019). Sedimentary and residual clays from Santiago, Boavista e Fogo (Cape Verde): Assessment of their properties as geophagic materials. Arab. J. Geosci. 12 (510), 1-10. https://doi.org/10.1007/ s12517-019-4668-6

Dittmar T., Hertkorn N., Kattner G. and Lara R.J. (2006). Mangroves, a major source of dissolved organic carbon to the oceans. Glob. Biogeochem. Cycles 20, 1-7. https://doi.org/10.1029/2005GB002570

Dong C.D., Chen C.F. and Chen C.H. (2012). Determination of polycyclic aromatic hydrocarbons in industrial harbor sediments by GC-MS. Int. J. Env. Res. Pub. He. 9 (6), 2175-2188. https://doi.org/10.3390/ ijerph9062175

Evans M., Davies M., Janzen K., Muir D., Hazewinkel R., Kirk J. and Boer D. (2016). PAH distributions in sediments in the oil sands monitoring area and western Lake Athabasca: Concentration, composition and diagnostic ratios. Environ. Pollut. 213, 671-687. https:// doi.org/10.1016/j.envpol.2016.03.014

Farias C.O., Hamacher C., Wagener A. and Scofield A. (2008). Origin and degradation of hydrocarbons in 
mangrove sediments (Rio de Janeiro, Brazil) contaminated by an oil spill. Org. Geochem. 39 (3), 289-307. https://doi.org/10.1016/j.orggeochem.2007.12.008

García E.M., Cruz-Motta J.J., Farina O. and Bastidas C. (2008). Anthropogenic influences on heavy metals across marine habitats in the western coast of Venezuela. Cont. Shelf. Res. 28 (20), 2757-2766. https://doi. org/10.1016/j.csr.2008.09.020

Garrigues P.and Ewald M. (1983). Identification of monomethylated polycyclic aromatic hydrocarbons in crude oils by liquid chromatography and high-resolution Shpol'skii effect fluorescence spectrometry. Anal. Chem. 55 (13), 2155-2159. https://doi.org/10.1021/ ac00263a035

Giger W. and Schaffner C. (1978). Determination of polycyclic aromatic hydrocarbons in the environment by glass capillary gas chromatography. Anal. Chem. 50 (2), 243-249. https://doi.org/10.1021/ac50024a020

Hesse P.R. (1971). A text book of soil chemical analysis. John Murray Publishers. London, England, 520 pp.

Hong Y.W., Yuan D.X., Lin Q.M. and Yang T.L. (2008). Accumulation and biodegradation of phenanthrene and fluoranthene by the algae enriched from a mangrove aquatic ecosystem. Mar. Pollut. Bull. 56 (8), 14001405. https://doi.org/10.1016/j.marpolbul.2008.05.003

Hwang H.M., Wade T.L. and Sericano J.L. (2003). Concentrations and source characterization of polycyclic aromatic hydrocarbons in pine needles from Korea, Mexico, and United States. Atmos. Environ. 37 (16), 2259-2267. https://doi.org/10.1016/S13522310(03)00090-6

Itoh N., Tamamura S. and Kumagai M. (2010). Distributions of polycyclic aromatic hydrocarbons in a sediment core from the north basin of Lake Biwa, Japan. Org. Geochem. 41 (8), 845-852. https://doi. org/10.1016/j.orggeochem.2010.04.002

Kaiser D., Schulz-Bull D.E. and Waniek J.J. (2016). Profiles and inventories of organic pollutants in sediments from the central Beibu Gulf and its coastal mangroves. Chemosphere 153, 39-47. https://doi.org/10.1016/j. chemosphere.2016.03.041

Khalili N.R., Scheff P.A. and Holsen T.M. (1995). PAH source fingerprints for coke ovens, diesel and gasoline engines, highway tunnels, and wood combustion emissions. Atmos. Environ. 29 (4), 533-542. https://doi. org/10.1016/1352-2310(94)00275-P

Kafilzadeh F., Shiva A.H. and Malekpou R. (2011). Determination of polycyclic aromatic hydrocarbons (PAHs) in water and sediments of the Kor river, Iran. Middle-East Journal of Scientific Research 10 (1), 1-7.

Killops S. and Al-Joboori M. (1990). Characterization of the unresolved complex mixture (UCM) in the gas chromatography of biodegraded petroleums. Org.
Geochem. 15 (2), 147-160. https://doi. org/10.1016/0146-6380(90)90079-F

Killops S. and Readman J.W. (1985). HPLC fractionation and GC-MS determination of aromatic hydrocarbons from oils and sediments. Org. Geochem. 8 (4), $247-$ 257. https://doi.org/10.1016/0146-6380(85)90003-8

Kristensen E., Bouillon S., Dittmar T. and Marchand C. (2008). Organic carbon dynamics in mangrove ecosystems: A review. Aquat. Bot. 89 (2), 201-219. https:// doi.org/10.1016/j.aquabot.2007.12.005

La Flamme R. and Hites R. (1978). The global distribution of polycyclic aromatic hydrocarbons in recent sediments. Geochim. Cosmochim. Ac. 42 (3), 298-303. https://doi.org/10.1016/0016-7037(78)90182-5

Leeming R. and Maher W. (1992). Sources of polycyclic aromatic hydrocarbons in Lake Burley Griffin, Australia. Org. Geochem. 18 (5), 647-655. https://doi. org/10.1016/0146-6380(92)90090-K

López L., Mogollón J.L., Aponte A. and Bifano C. (2000). Identification of anthropogenic organic contamination associated with the sediments of a hypereutropic tropical lake, Venezuela. Environ. Geochem. Hlth. 22 (1), 55-74. https://doi.org/10.1023/A:1006715608508

Marchand N., Besombes J.L., Chevron N., Masclet P., Aymoz G. and Jaffrezo J.L. (2004). Polycyclic aromatic hydrocarbons (PAHs) in the atmospheres of two French alpine valleys: sources and temporal patterns. Atmos. Chem. Phys. 4, 1167-1181. https://doi.org/10.5194/ acp-4-1167-2004

Marques dos Santos M., Almeida Brehm F., Filippe T.C., Reichert G. and Rodrigues de Azevedo J.C. (2017). PAHs diagnostic ratios for the distinction of petrogenic and pirogenic sources: Applicability in the Upper Iguassu Watershed - Parana, Brazil. Revista Brasileira de Recursos Hídricos 22, 9. https://doi. org/10.1590/2318-0331.011716084

Mater L., Alexandre M.R., Hansel F.A. and Madureira L.A.S. (2004). Assessment of lipid compounds and phosphorus in mangrove sediments of Santa Catarina Island, SC, Brazil. J. Braz. Chem. Soc. 15 (5), 725-734. https://doi.org/10.1590/S010350532004000500019

McLeod E., Chmura G.L., Bouillon S. and Salm R. (2011). A blueprint for blue carbon: toward an improved understanding of the role of vegetated coastal habitats in sequestering $\mathrm{CO}_{2}$. Front. Ecol. Environ. 9, 552-560. https://doi.org/10.1890/110004

Munsell A.H. (1973). Munsell soil color charts. Macbeth Division of Kollmorgen Corporation. Baltimore, Maryland, USA, 29 pp.

Molnar N., Welsh D.T., Marchand C., Deborde J. and Meziane T. (2013). Impacts of shrimp farm effluent on water quality, benthic metabolism and $\mathrm{N}$-dynamics 
in a mangrove forest (New Caledonia). Estuar. Coast. Shelf. Sci. 117, 12-21. https://doi.org/10.1016/j. ecss.2012.07.012

Paez-Osuna F. (2001). The environmental impact of shrimp aquaculture: causes, effects, and mitigating alternatives. Environ. Manage. 28, 131-140. https:// doi.org/10.1007/s002670010

Peters K., Walters C. and Moldowan J. (2005). The biomarker guide. Cambridge University Press, Cambridge, 706 pp.

Ranjan R.K., Routh J., Ramanathan A.1. and Val Klump J. (2012). Polycyclic aromatic hydrocarbon fingerprints in the Pichavaram mangrove-estuarine sediments, southeastern India. Org. Geochem.5 3, 88-94. https:// doi.org/10.1016/j.orggeochem.2012.08.007

Ranjan R.K., Routh J., Val Klump J. and Ramanathan A.l. (2015). Sediment biomarker profiles trace organic matter input in the Pichavaram mangrove complex, southeastern India. Mar. Chem. 171 (20), 44-57. https:// doi.org/10.1016/j.marchem.2015.02.001

Ravindra K., Sokhi R. and Van Grieken R. (2008a). Atmospheric polycyclic aromatic hydrocarbons: source attribution, emission factors and regulation. Atmos. Environ. 42 (13), 2895-2921. https://doi.org/10.1016/j. atmosenv.2007.12.010

Ravindra K., Wauters E. and Van Grieken R. (2008b). Variation in particulate PAHs levels and their relation with the transboundary movement of the air masses. Sci. Total. Environ. 396 (2-3), 100-110. https://doi. org/10.1016/j.scitotenv.2008.02.018

Silva T., Almeida Azevedo D. and Aquino Neto F.R. (2007). Distribution of polycyclic aromatic hydrocarbons in surface sediments and waters from Guanabara Bay, Rio de Janeiro, Brazil. J. Braz. Chem. Soc. 18 (3), 628-637. https://doi.org/10.1590/S010350532007000300021

Simpson C.D., Mosi A.A., Cullen W.R. and Reimer K.J. (1996). Composition and distribution of polycyclic aromatic hydrocarbon contamination in surficial marine sediments from Kitimat Harbor, Canada. Sci. Total. Environ. 181 (3), 265-278. https://doi. org/10.1016/0048-9697(95)05026-4
Tsibart A.S. and Gennadiev A.N. (2013). Polycyclic aromatic hydrocarbons in soils: sources, behavior, and indication significance (a review). Eurasian. Soil. Sci. 46 (7), 728-741. https://doi.org/10.1134/S1064229313070090

Tobiszewski M. and Namieśnik J. (2012). PAH diagnostic ratios for the identification of pollution emission sources. Environ. Pollut. 162, 110-119. https://doi. org/10.1016/j.envpol.2011.10.025

Tobiszewski M. (2014). Application of diagnostic ratios of PAHs to characterize the pollution emission sources. Proceedings. 5th International Conference on Environmental Science and Technology. Singapore, Singapore. 19-20 February, 2014.

Volkman J.K., Revill A.T. and Murray A.P. (1997). Application of biomarkers for identifying sources of natural and pollutant hydrocarbons in aquatic environments, In: Molecular markers in environmental geochemistry (R.P. Eganhouse, Ed.). American Chemical Society, Washington, DC, USA, pp. 110-132. https://doi. org/10.1021/bk-1997-0671.ch008

Walker S.E., Dickhut R.M., Chisholm-Brause C., Sylva S. and Christopher M.R. (2005). Molecular and isotopic identification of PAH sources in a highly industrialized urban estuary. Org. Geochem. 36 (4), 619-632. https:// doi.org/10.1016/j.orggeochem.2004.10.012

Wang C., Zhou S., He Y., Wang J., Wang F. and Wu S. (2017). Developing a black carbon-substituted multimedia model for simulating the PAH distributions in urban environments. Scientific Reports 7, 14548. https://doi.org/10.1038/s41598-017-14789-9

Yunker M.B., Macdonald R.W., Vingarzan R., Mitchell R.H., Goyette D. and Sylvestre S. (2002). PAHs in the Fraser River basin: A critical appraisal of PAH ratios as indicators of PAH source and composition. Org. Geochem. 33 (4), 489-515. https://doi.org/10.1016/ S0146-6380(02)00002-5

Zhang Y., Liu M., Chen H. and Hou G. (2014). Source identification of polycyclic aromatic hydrocarbons in different ecological wetland components of the Qinkenpao wetland in Northeast China. Ecotox. Environ. Safe. 102, 160-167. https://doi.org/10.1016/j. ecoenv.2014.01.030 